\title{
ІНФОРМАЦЙНІ ТЕХНОЛОГІЇ
}

УДК 004.891

\author{
к.т.н., доц. Джулій В.М. (ХмНУ) \\ к.т.Н., доц. Муляр І.В. (ХмНУ) \\ д.т.н., с.н.с. Сєлюков О.В. (КНУБіА) \\ к.Т.н., доц. Чешун В.М. (ХмНУ)
}

Коровченко Д.В. (в/ч А1671, м. Рівне)

Берназ А.А. (коледж Мiciacapa, Торонто)

DOI: https://doi.org/10.17721/2519-481X/2019/65-04

\section{ІЄРАРХІЧНА МЕРЕЖЕВА МОДЕЛЬ ІНФОРМАЦИЙНОГО ЗАБЕЗПЕЧЕННЯ ПОДАННЯ ПРЕДМЕТНОЇ ОБЛАСТІ}

У статті запропоновано підхід до визначення ісрархічної мережевої моделі інформаційного забезпечення подання предметної області. Ісрархічна мережева модель відображає взаємозв'язок інформаційних об'єктів за рівнями підпорядкованості.

Одне з ключових питань в розробці інформаційного забезпечення - вибір моделі подання контенту таким чином, щоб забезпечити найбільш ефективну роботу з нею як користувача, так і розробника. Можна виділити два основних підходи - емпіричний і теоретичний. Перший заснований на вивченні принципів організацї людської пам'яті і моделюванні механізмів вирішення задач людиною. Другий підхід можна визначити як теоретично обтрунтований, що гарантує правильність рішень, а відповідні йому моделі - формальними моделями подання знань. Послідовність застосування матеріалів включена до складу моделі, оскільки ефективність сприйняття матеріалу залежить, в тому числі, від того, наскільки людина «готова» сприймати запропоновану інформацію, тобто, має досить базових знань.

Залежно від виду вхідних даних запропоновано можливі способи формування ісрархічних мережсевих моделей інформаційного забезпечення. Якщц вхідні дані представлені множиною інформаційних елементів, кількість яких с порівняно невеликою і придатною для застосування експертних методів, запропоновано алгоритм побудови ісрархічної мережевої дворівневої моделі інформаційного забезпечення. Якщц вхідні дані представлені «деревом знань», тобто, ісрархічною моделлю інформаційного забезпечення, запропоновано алгоритм побудови ісрархічної мережевої моделі.

Ісрархічна мережева модель інформаційного забезпечення призначена для управління процесами придбання та використання знань, що дозволяе враховувати корисності інформаційних елементів і дидактичні зв'язки між ними. Запропоновано спосіб формування інформаційного забезпечення, призначений для ісрархічного мережевого представлення предметної області, щцо дозволяс структурувати контент інформаційно-довідкових та інших систем, які відрізняються від відомих використанням взаємопов'язаних етапів відбору, кластеризації та впорядкування контенту.

Отримані результати можуть бути використані для підтримки прийняття рішень при придбанні та застосуванні знань: при розробці програм окремих курсів підвищення кваліфікації; інформаційного забезпечення систем електронного навчання; при формуванні програм дистанційної освіти; при розробці та наступному коригування навчальних планів; формуванні навчальних, довідкових матеріалів, курсів лекцій для окремих дисциплін.

Ключові слова: алгоритм, інформаційний елемент, контент, модель, інформаційне забезпечення, предметна область, інформація.

Вступ. На сьогоднішній день швидкість оновлення знань і накопичення інформації безперервно збільшується, тому як сама людина, так і організації виявляються залучені в постійний процес управління знаннями та інформаційним забезпеченням. Сьогодні, як ніколи, підприємства всіх типів залежать від технології досягнення своїх ділових результатів, будь то виробнича компанія, яка виробляє автомобілі, лікарня, яка доглядає за пацієнтами, або ресторан, який подає їжу подружжю у нічний час [1]. 3 моменту впровадження комп'ю- 
терних технологій у бізнес існує підтримка користувачів, продуктивність роботи персоналу залежить від технологій автоматизації, а організації залежать від якості служб підтримки інформаційних технологій (IT) для швидкого відновлення та запобігання будь-якому простою через будь-який збій у технології або ії використанні [2]. Оскільки бізнес настільки залежить від IT-послуг, підприємства все більше піднімають планку для IT-послуг, коли мова йде про їх доступність, а самі IT поряд з більшою доступністю повинні відповідати більшим вимогам надійності [1]. Досягти бажаного результату можливо лише з урахуванням актуального досвіду і знань створення ефективних IT-систем. 3 іншої сторони, стандартизація систем та швидкість, з якою знання стають застарілими, означають, що технічні знання з боку персоналу отримують та відкидають на постійній основі [2].

Важливу роль в інформаційному забезпеченні процесу набуття знань 3 предметної області відіграють моделі подання знань. Зважаючи на великий обсяг доступних інформаційних ресурсів, актуальним стає питання розробки інструментарію, що дозволяє підвищити результативність освоєння інформації, зокрема, за рахунок створення умов для найбільш успішного освоєння контенту предметної області за допомогою підвищення якості підготовки інформаційного забезпечення.

Одне з ключових питань в розробці інформаційного забезпечення - вибір моделі подання контенту таким чином, щоб забезпечити найбільш ефективну роботу з нею як користувача, так і розробника.

Аналіз останніх досліджень і публікацій. На даний час розроблено безліч моделей представлення знань. Вони різняться за призначенням, за ідеями, що лежать в їх основі, а також з точки зору математичної обгрунтованості.

У роботі [2] проведене дослідження з метою оцінки, як організація може концептуалізувати управління знаннями IT-підтримки з метою отримання максимальної продуктивності для користувачів. Підхід до обгрунтованої теорії використовується для дослідження діяльності та процесів управління знаннями, присутніми в групі електронних та інформаційних технологій багатодисциплінарного науково-дослідного центру під назвою iThemba Laboratory for Accelerator Science (LABS). По-перше, підхід передбачав спостереження учасників для збору інформації про робочий потік підтримки ЕIT, що формує першу спробу відкритого кодування. По-друге, напівструктуровані інтерв'ю, а також використання методики репертуарної сітки були використані для збору різноманітних поглядів персоналу. Це дослідження показало, що основою управління знаннями для IT-підтримки є стратегія та культура, заснована на конструкціях прихильності та взаємності. 3 цього викладена адаптована модель КМ для служби IT-підтримки.

В [1] описується модель багаторівневої підтримки для своєчасного реагування та вирішення питань від користувачів, що складається з трьох рівнів: рівень 1 - служба обслуговування; рівень 2 - команди технічного управління або управління додатками; рівень 3 - підтримка розробника чи постачальника. Автором сформульовано принципи визначення ресурсів для вирішення проблем на основі запропонованої моделі.

Існує велика кількість спеціалізованих моделей.

У статті [3] розглянуто різні потенційні компоненти моделі підтримки інформаційних технологій вищої освіти, а також те, як ці частини розгортаються в коледжі Babson для задоволення конкретних інституційних потреб та потреб користувачів. Запропоновано нову систему надання послуг, якою передбачена децентралізація підтримки на місцях, аутсорсинг підтримки стандартних програмних додатків та збереження як централізоване вирішення проблем на високому рівні в мережі.

У роботі [4] проведене дослідження ролі інформації та інформаційного забезпечення у становленні та розвитку економіки, заснованої на знаннях. Запропоновано модель організації загальнонаціонального інформаційного забезпечення економіки для вирішення проблеми надання економічним суб'єктам достовірної, оперативної та пертинентної інформації, щоб асиметрія інформації менше впливала на їх діяльність. Запропонована в [5] організаційноекономічна модель управління інформаційним забезпеченням виробничої діяльності підприємства, яка визначає свою сумісну частину, формує їх внутрішню і зовнішню взаємодії для 
ефективної реалізації цілей і задач систем інформаційного забезпечення. У статті [6] розроблено концептуальну структурно-ієрархічну модель системи інформаційного забезпечення якості промислової продукції у вигляді замкнутого контуру із зворотними зв'язками між нормативним, виробничим та інформаційним модулями виробництва. Використання моделі дає можливість на інформаційному рівні забезпечити наукові принципи стандартизації при вирішенні задач управління якістю продукції на стадіях життєвого циклу.

В [7] обгрунтовано концептуальну модель розвитку системи інформаційного забезпечення наукової та інноваційної діяльності у медичній галузі.

Авторами [8] запропонована імовірнісна модель встановлення інформаційної взаємодії в мережі інтернет речей за топологією mesh, заснована на мультиагентному підході, побудована 3 урахуванням фундаментальних характеристик технології інтернет речей. Модель дозволяє оцінити абсолютні та імовірнісні характеристики інформаційної взаємодії. У моделі враховані умови, відповідні реальному процесу інформаційної взаємодії - наявність непрацездатних каналів і точок доступу, обмежена кількість повторних спроб встановлення з'єднань, наявність альтернативних маршрутів.

В роботі [9] розглянуто екосистему програмного забезпечення як систему з трьох взаємодіючих елементів: навколишнє середовище, програмне забезпечення та людина. Проаналізовані причини і передумови застосування екологічного підходу до досліджень програмного забезпечення. Описано компоненти екосистем програмного забезпечення. Розглянута матрична модель екосистеми і описані матриці взаємодії. Показані і описані форми взаємодії між компонентами екосистеми програмного забезпечення. Побудована модель інформаційної взаємодії в екосистемі.

Нечітка мережева модель формування цілей інформаційного забезпечення [10], призначена для управління процесами придбання i/або використання знань, що дозволяє враховувати корисності інформаційних елементів і дидактичні зв'язки між ними. Спосіб формування інформаційного забезпечення дозволяє структурувати контент інформаційно-довідкових та інших систем, він заснований на взаємопов'язаних етапах відбору, кластеризації та впорядкування контенту. Отримані результати можуть бути використані для підтримки прийняття рішень при придбанні та застосуванні знань: при розробці програм окремих курсів підвищення кваліфікації; інформаційного забезпечення систем електронного навчання; при формуванні програм дистанційної освіти; при розробці та наступним коригуванням навчальних планів; формуванні навчальних, довідкових матеріалів, курсів лекцій для окремих дисциплін.

Незважаючи на велике різноманіття моделей інформаційного забезпечення подання предметної області, нинішня структура підтримки IT насправді не йде в ногу з розвитком самих IT [11]. Поки існує будь-яка технологія, існує потреба вирішити проблеми 3 нею, що зумовлює актуальність вдосконалення існуючих моделей і створення нових.

За результатами дослідження можна виділити два основних підходи в створенні моделей інформаційного забезпечення подання предметної області - емпіричний і теоретичний (рис. 1). Емпіричний підхід заснований на вивченні принципів організації людської пам'яті і моделюванні механізмів вирішення задач людиною. Теоретичний підхід можна визначити як теоретично обгрунтований, що гарантує правильність рішень, а відповідні йому моделі - формальними моделями подання знань.

На основі емпіричного підходу в даний час розроблені і отримали найбільшу популярність продукційні, мережеві, фреймових моделі, ленеми. Умовно, до групи емпіричного підходу можна включити нейронні мережі та генетичні алгоритми, які відносяться до біонічного напрямку штучного інтелекту.

Теоретичний підхід представлений моделями, заснованими на формальній логіці: логічні, комбінаторні, алгебраїчні моделі представлення знань, формальні граматики. 


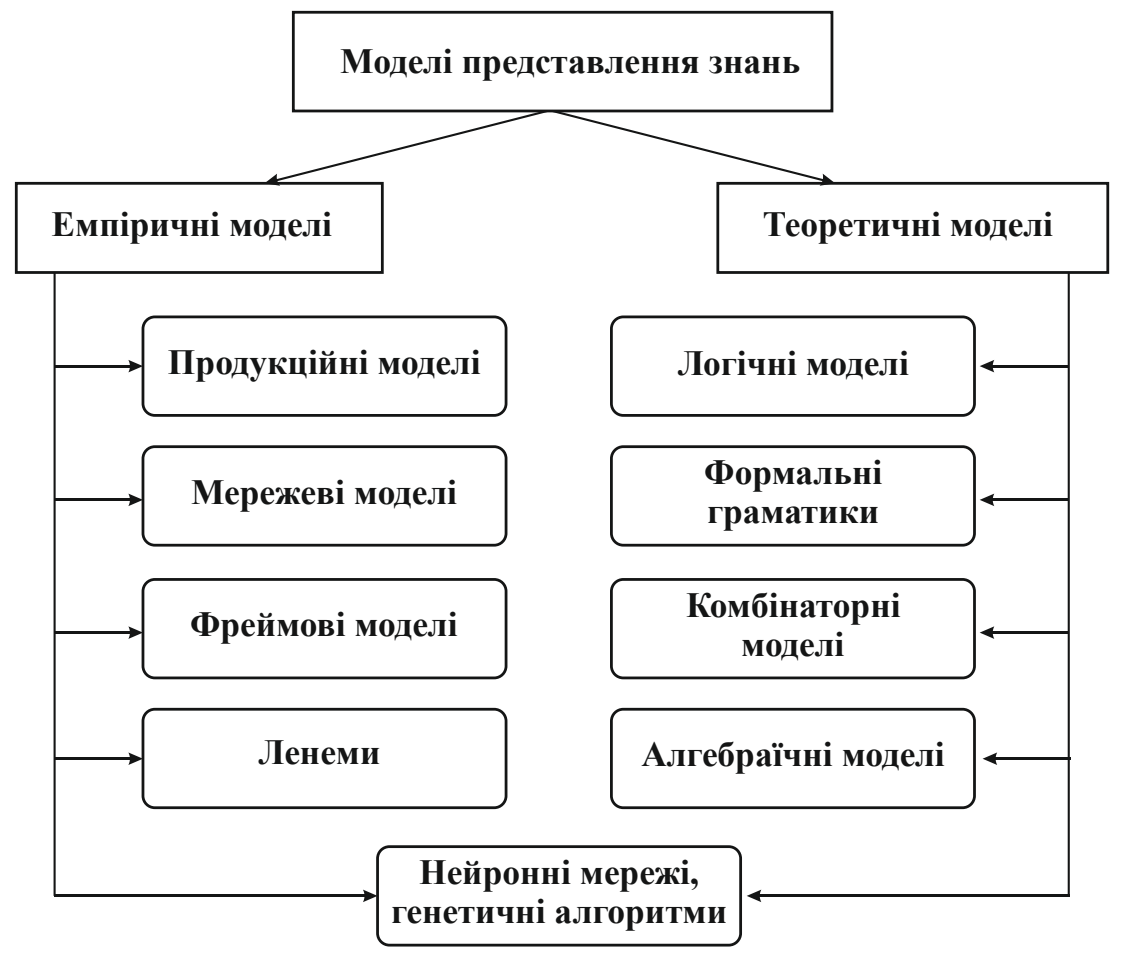

Рисунок 1 - Класифікація моделей подання знань

В інженерії знань під мережевою моделлю представлення знань застосовується орієнтований граф, що відображає зміст цілісного образу. Семантична мережа - це орієнтований граф, вершинам якого зіставлені поняття, а дугам - відношення між ними. Формально мережу можна задати у вигляді $H=\langle I, C, G>$, де $I$ - множина інформаційних одиниць; $C$ - множина типів зв'язків між інформаційними одиницями; $G$ - відображення, що задає конкретні відношення з наявних типів $C$ між елементами $I$.

Основна перевага семантичної моделі пов'язана з відповідністю сучасним представленням про організацію довготривалої пам'яті людини. Недолік моделі - складність пошуку і виведення на семантичній мережі.

Постановка задачі. На основі розглянутих моделей комунікації [1-21] можна зробити висновок, що в першу чергу необхідно встановити відношення відповідності або невідповідності кодів джерела і приймача (оцінити можливість комунікації) і на наступному етапі визначити вплив на ефективність комунікації лексікодів обох сторін. В загальному випадку можна говорити, що на можливість комунікації вирішальний (хоча і не єдиний) вплив надає співвідношення кодів джерела і приймача, а на ефективність (правильність осмислення, розуміння) більшою мірою впливає перетин лексікодів.

Таким чином, можна зробити висновок, що ефективність освоєння матеріалу істотно залежить від того, чи «готовий» лексікод (тезаурус) навчаючого до внесення в нього пропонованої інформації, будь то підручник, довідкові матеріали або живе спілкування з педагогом. 3 огляду на те, що тезаурус здатний змінюватися, розширюватися під впливом нової інформації, найбільш ефективним можна назвати процес навчання, організований таким чином, щоб кожен новий фрагмент матеріалу (нове повідомлення) мав істотний перетин з тезаурусом навчаючого і створював можливість для його розширення (тобто, містив певний обсяг нової інформації, що виходить за рамки поточного лексікоду навчаючого).

Отже, на ефективність засвоєння матеріалу в значній мірі буде впливати «плавність» розширення тезаурусу навчаючого, тобто, той порядок, в якому представлені матеріали будуть вивчатися, і як буде зростати обсяг нових знань.

Ієрархічна модель предметної області відображає взаємозв'язок інформаційних об'єктів за рівнями підпорядкованості. На самому верхньому (кореневому, нульовому) рівні розташований єдиний інформаційний об'єкт. Він складається з декількох інформаційних об'єктів 
другого рівня. Кожен інформаційний об'єкт другого рівня включає кілька інформаційних об'єктів третього рівня тощо. На рис. 2 представлена ієрархічна модель предметної області, де $X$ - інформаційна множина, яка відповідає розглянутій предметній області. Всі матеріали інформаційної множини можуть бути розділені на інформаційні фрагменти $C_{i}$, які, в свою чергу, можуть містити інформаційні фрагменти нижчого рівня. Інформаційні фрагменти нижнього рівня складаються з інформаційних елементів $x_{n}, n=\overline{1, N}$, що є неподільними на даному рівні розгляду фрагментів контенту.

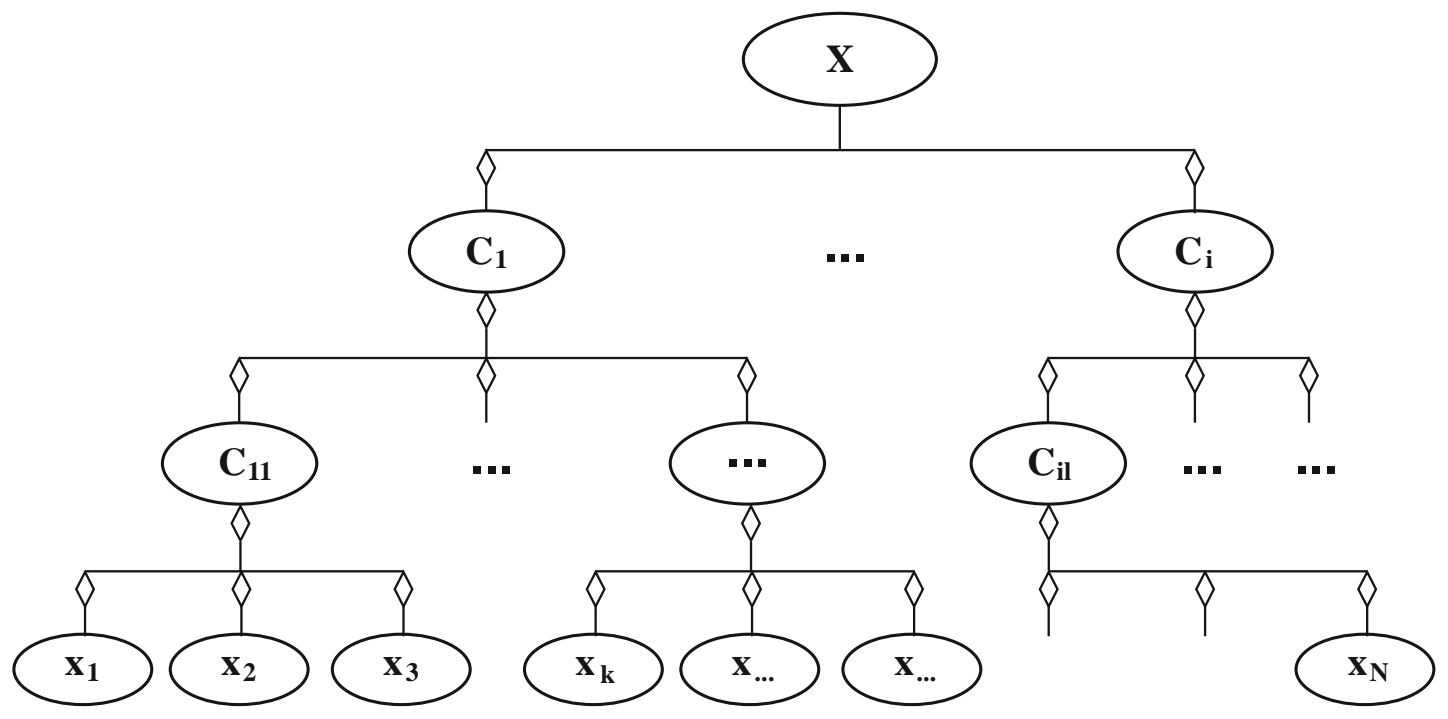

Рисунок 2 - Ієрархічна модель предметної області

За допомогою ієрархічних моделей зручно описувати зміст освітніх програм, що складаються з дисциплін, розділів, тем і навчальних елементів. В даному випадку, інформаційна множина $X$ визначається навчальним планом освітньої програми. Дисципліни представляють інформаційні фрагменти першого (верхнього) рівня і $C_{i}$, теми дисциплін - інформаційні фрагменти другого рівня $C_{i j}$, окремі навчальні елементи (визначення, теореми і т.д.) відповідають інформаційним елементам $x_{n}$.

Ієрархічні моделі предметних областей широко застосовуються на сьогоднішній день в різних сферах інформаційного забезпечення. Однак ієрархічні моделі не підтримують відношення дидактичної упорядкованості інформаційних елементів. Наявність дидактичного зв'язку між будь-якими двома елементами означає, що вивчення (засвоєння) одного елемента базується на знанні іншого, тобто, вимагає його попереднього засвоєння. Оскільки ієрархічні моделі предметної області не допускають наявності горизонтальних зв'язків між елементами одного і того ж рівня ієрархії, якими представляються дидактичні зв'язки, то відсутня можливість визначення порядку освоєння інформаційних фрагментів і інформаційних елементів. Таким чином, можна зробити висновок про недоліки застосування тільки ієрархічних моделей для опису предметних областей при розробці інформаційного забезпечення в цілях придбання нових знань.

3 розвитком комп'ютерних i web-технологій все більш широке застосування знаходить електронний (віддалений) режим навчання. Однак, в більшості випадків, реалізація такого режиму навчання заснована на забезпеченні того, хто навчається, великим об'ємом статичних електронних ресурсів без урахування здібностей учня і без підтримки активного навчального процесу.

Для керування навчальними ресурсами може застосовуватися семантична модель мережі знань, заснована на онтологіях і тематичних картах (рис. 3). Тематичні карти, зазвичай, використовуються для представлення та організації знань у такий спосіб, який може бути оптимізований для навігації. Модель мережі знань включає в себе наступні елементи: 
1. Теми представляють елементи знань. Кожна тема має додаткові атрибути, такі як приналежність до категорії та інші.

2. Зв'язки визначають відношення між темами, включаючи генералізацію, агрегацію та посилання (наприклад, причинно-наслідкові зв'язки, аналогії тощо).

3. Навчальні матеріали. Кожна тема може бути пов'язана з одним або більше навчальними матеріалами. Атрибутами можуть бути ключові слова, тип елемента, педагогічне призначення, рівень складності тощо.

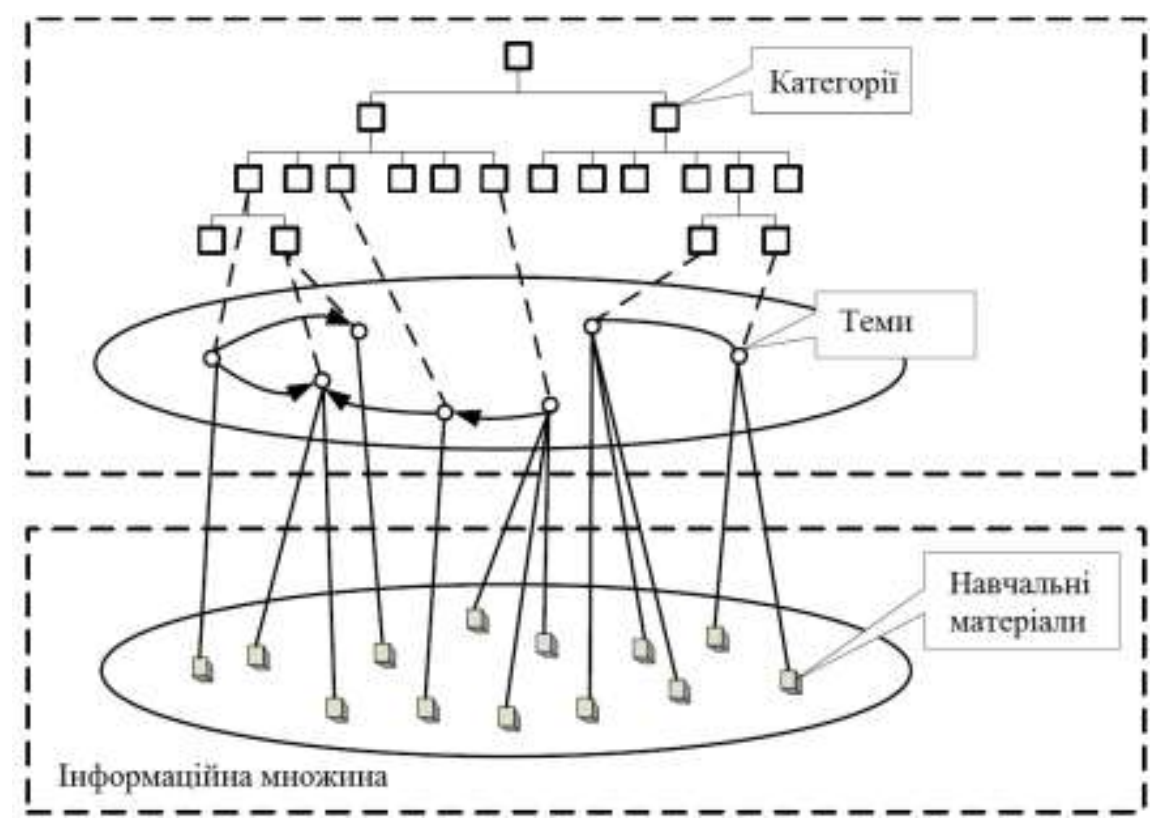

Рисунок 3 - Модель мережі знань

У рамках інформаційно-навчальної системи (IНC) адаптивні навчальні курси (індивідуальні траєкторії навчання) можуть бути сформовані на основі онтології, зв'язків між темами і профілю того, хто навчається. У відповідь на запит, сформований навчаючим і відображаючий мету навчання, IНC генерується індивідуальна траєкторія, що направляє навчання відповідно до його цілі.

Основна частина. Якість інформаційного забезпечення можна розглядати в двох аспектах - зміст і структура. Остання, в свою чергу, включає в себе модель інформаційнодовідкового контенту і послідовність його застосування $[5,7]$. Зважаючи на великий обсяг доступних інформаційних ресурсів, актуальним стає питання розробки процедур, що дозволяють підвищити результативність засвоєння інформації, зокрема, за рахунок створення умов для найбільш успішного освоєння контенту предметної області за допомогою підвищення якості підготовки інформаційного забезпечення для технічних додатків в промислових системах.

Опис предметної області за допомогою лише мережевих або ієрархічних моделей не $\epsilon$ достатнім для подання інформаційного забезпечення, тому запропонована для використання узагальнена ієрархічна мережева модель.

Залежно від виду вхідних даних розглянемо можливі способи формування ієрархічних мережевих моделей інформаційного забезпечення.

У першому випадку вхідні дані представлені множиною інформаційних елементів, кількість яких порівняно невелика і $є$ припустимою для застосування експертних методів. Сукупність етапів побудови ієрархічної мережевої моделі приведено на рис. 4. 


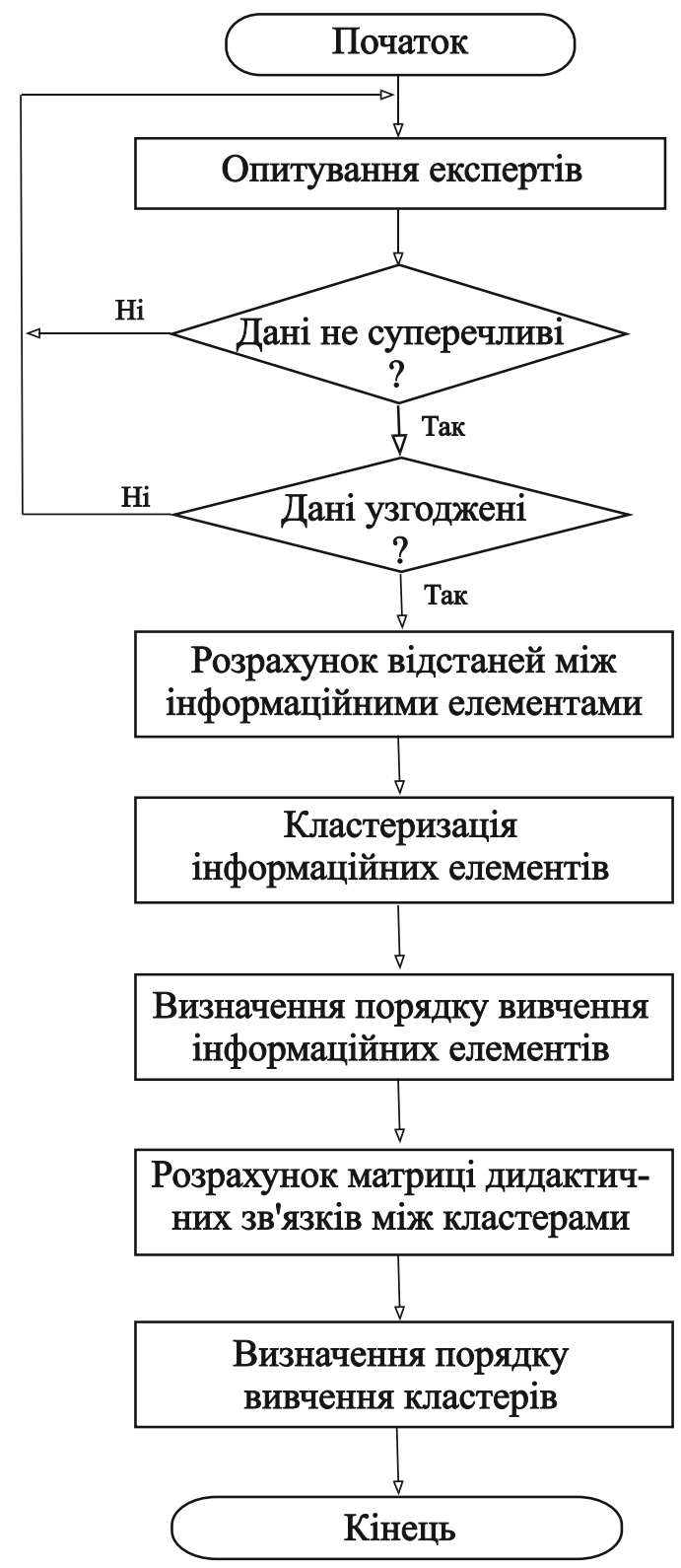

Рисунок 4 - Алгоритм побудови ієрархічної мережевої дворівневої моделі інформаційного забезпечення

У другому варіанті вхідні дані представлені «деревом знань», тобто, ієрархічною моделлю інформаційного забезпечення. Сукупність етапів побудови ієрархічної мережевий моделі наведена на рис. 5.

Визначення структури інформаційного забезпечення та порядку засвоєння знань предметної області представлена на рис. 6 , де $W$ - матриця ваг дидактичних зв'язків між інформаційними елементами (IE), $D$ - матриця відстаней між IE, $R$ - порядок вивчення IE, $C_{L}-$ кластери інформаційних елементів, що $є$ інформаційними фрагментами (IФ), $W_{L}$ - матриця ваг дидактичних зв'язків між кластерами на рівні $L, r_{i q}$ - порядок вивчення IФ. 


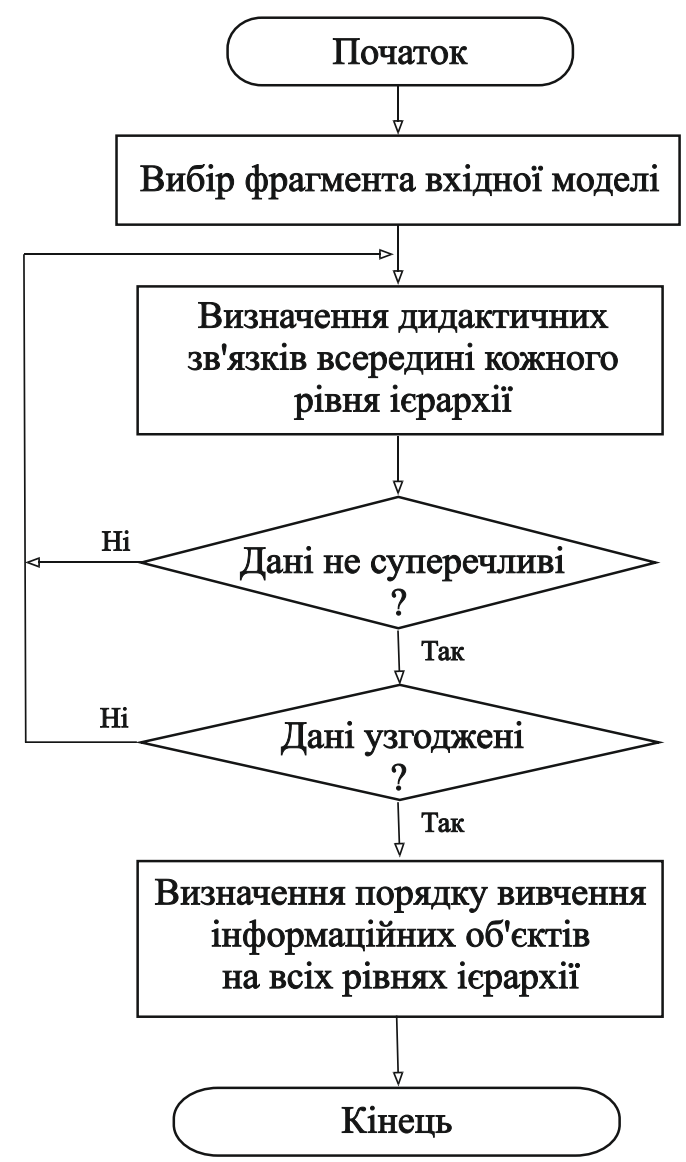

Рисунок 5 - Алгоритм побудови ієрархічної мережевої моделі

Процедура визначення структури інформаційного забезпечення складається 3 наступних кроків: визначення близькості між IE; кластеризація усієї множини відібраних навчальних елементів (формування ІФ); визначення дидактичних зв'язків між ІФ та формування структури контенту верхнього рівня; впорядкування IE всередині кластерів; визначення близькості між кластерами; впорядкування кластерів.

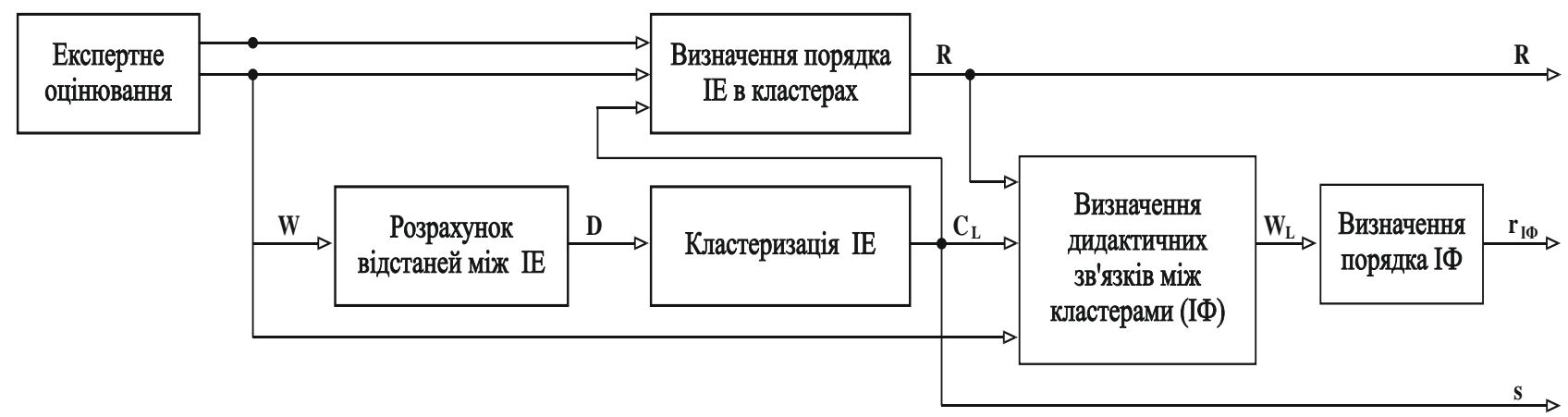

Рисунок 6 - Визначення структури та порядку освоєння знань предметної області

На основі отриманої ієрархічної мережевої моделі інформаційного забезпечення, необхідно сформувати траєкторію роботи з об'єктами предметної області (IФ та IE). На кожному 3 ієрархічних рівнів, визначається лінійний порядок їх застосування або вивчення. На кожному з рівнів модель дидактичних зв'язків між IФ (IE) представлена квадратною матрицею $W_{L}$.

Для вирішення задачі формування траєкторії роботи з інформаційними об'єктами предметної області можуть застосовуватися алгоритми побудови ярусно-паралельної форми графу, зокрема, алгоритми топологічної сортування. Задача топологічного сортування графу полягає в наступному: вказати такий лінійний порядок на його вершинах, щоб будь-яке реб- 
ро було спрямоване від вершини з меншим номером до вершини з більшим номером. Очевидно, якщо в графі є цикли, то такого порядку не існує.

Якщо при вирішенні задачі визначення траєкторії засвоєння матеріалу необхідно розглянути всі IE 3 деякої предметної області, то задача може бути сформульована як варіант задачі комівояжера. В даному випадку задача комівояжера є асиметричною, оскільки моделюється орієнтованою граф-структурою, яка є незамкненою, тому що повертатися до стартової вершини не вимагається. При цьому "критерій вигідності маршруту" відображає логічність (тобто, дидактичну впорядкованість) розгляду матеріалу, сприяючи кращому його сприйняттю яке можна трактувати відповідно до семантичної теорії інформації Шрейдера. Для успішного засвоєння деякого IE потрібно вивчити всі IE, від яких в моделі дидактичних зв'язків $є$ дуги до поточного IE. Порушення цієї умови призводить до погіршення характеристик розглянутого маршруту, тобто до зменшення значення цільової функції, що характеризує траєкторію засвоєння матеріалу.

Одним з етапів побудови ієрархічної мережевої моделі інформаційного забезпечення $є$ відбір інформаційних елементів, які забезпечують формування заявлених цілей інформаційного забезпечення. Проаналізуємо визначення складу інформаційних елементів.

Дано множину доступних IE $X=\left\{x_{1}, x_{2}, \ldots, x_{N}\right\}, W-(N \times N)$ - матриця ваг дидактичних зв'язків між IE з елементами $w_{i l}, U-(N \times N)$ - матриця корисностей IE для формування цілей $J=\left[J_{1}, J_{2}, \ldots, J_{M}\right]^{T}$ інформаційного забезпечення з елементами $u_{i j}$.

Кожен IE $x_{n}$ характеризується об'ємом $v_{n}, n=\overline{1, N}$ (наприклад, трудомісткістю засвоєння). Для досягнення цілей інформаційного забезпечення потрібно застосувати деякий набір матеріалів, об'єм якого також обмежений. Потрібно визначити таку підмножину $S \subseteq X \mathrm{IE}$, застосування яких забезпечить максимально можливий ступінь досягнення сукупності цілей $J$ інформаційного забезпечення, враховуючи взаємозв'язок IE між собою, виражений матрицею дидактичних зв'язків, корисність окремих IE для досягнення цілей $J$, а також обмеження на максимальний загальний об'єм обраних IE. Процедура оцінки сформованості цілей інформаційного забезпечення представлена на рис. 7.

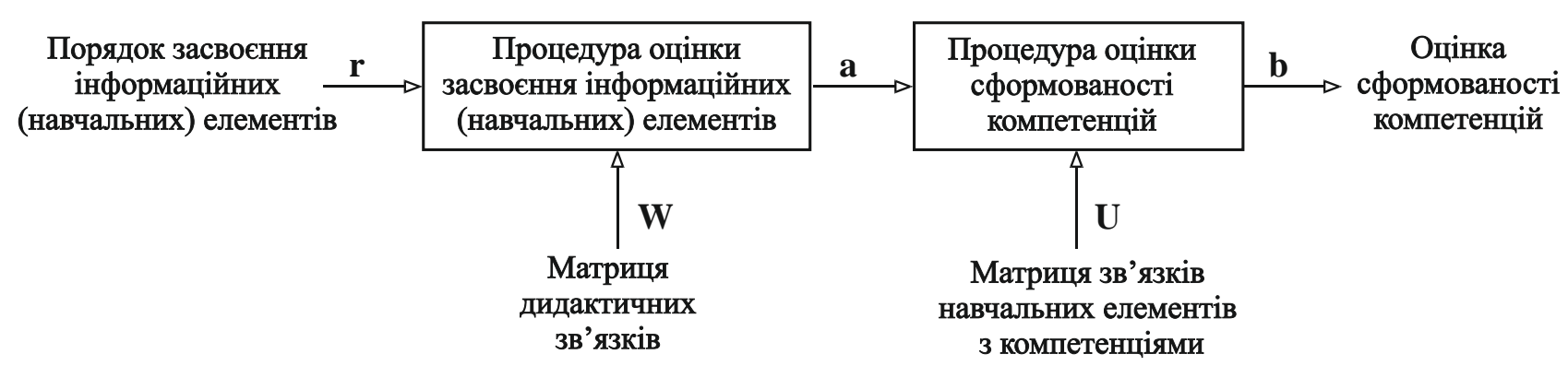

Рисунок 7 - Процедура оцінки сформованості цілей інформаційного забезпечення

Таким чином, залежно від виду вхідних даних запропоновано два можливі способи формування ієрархічних мережевих моделей інформаційного забезпечення.

Для вхідних даних, представлених множиною інформаційних елементів, кількість яких порівняно невелика і $є$ придатною для застосування експертних методів, запропонований алгоритм побудови ієрархічної мережевої дворівневої моделі інформаційного забезпечення. Прикладами задач $з$ такими вхідними даними можуть служити формування тематичного плану дисципліни, довідкового посібника, структури курсів підвищення кваліфікації тощо. Експертним шляхом встановлюються дидактичні зв'язки між IE, що відображають відношення парної впорядкованості при розгляді (застосуванні) IE. Виконуються перевірки на несуперечливість та узгодженість (якщо експертів було декілька). В результаті формується мережева модель інформаційного забезпечення. Якщо експертами застосовувалися не бінар- 
ні оцінки парної дидактичної впорядкованості, то формується зважена мережева модель інформаційного забезпечення.

Для вхідних даних, представлених «деревом знань» (ієрархічною моделлю інформаційного забезпечення), запропонований алгоритм побудови побудови ієрархічної мережевої моделі. Прикладами таких моделей є дерево понять «Computing Classification System», різні довідкові ресурси (в тому числі побудовані на wiki движку), класифікатори (УДК, ДРНТІ) тощо.

Для формування вхідних даних при побудові моделей предметної області використовуються експертні оцінки, які складають групу методів, що найбільш часто використовуються в практиці оцінювання складних систем на якісному рівні. Опитування експертів полягає в заслуховуванні і фіксації в змістовній та кількісній формі суджень експертів з розв'язуваної проблеми.

Висновки. Для досягнення цілей інформаційного забезпечення запропоновано шляхи підвищення ефективності набуття знань, зокрема, за допомогою аналізу і синтезу структури інформаційного забезпечення та визначення послідовності інформаційних об'єктів предметної області. Також запропонований підхід визначення такої траєкторії освоєння матеріалу, яка безпосередньо сприяє досягненню мети інформаційного забезпечення на основі вже наявних знань.

Запропоновано спосіб формування інформаційного забезпечення, призначений для ієрархічного мережевого представлення предметної області, що дозволяє структурувати контент інформаційно-довідкових та інших систем, що відрізняється від відомих використанням взаємопов'язаних етапів відбору, кластеризації та впорядкування контенту.

Отримані результати можуть бути використані для підтримки прийняття рішень при придбанні та застосуванні знань, а саме: при створенні інформаційного забезпечення виробничих процесів, в частині розробки елементів методичного забезпечення інформаційних систем, в корпоративних системах навчання персоналу; при розробці програм окремих курсів підвищення кваліфікації, а так само комплексів програм з подальшим їх коригуванням; інформаційного забезпечення систем електронного навчання; при формуванні програм дистанційної освіти; при розробці та наступним коригуванням навчальних планів; формуванні навчальних, довідкових матеріалів, курсів лекцій для окремих дисциплін.

\section{ЛІТЕРАТУРА:}

1 Dooley, P. Evaluating Technical Support Models: Tiered Support vs. Swarming, Part 1. [Electronic resource]. - Mode of access: https://optimalconnections.wordpress.com /2017/08/07/evaluating-technicalsupport-models-tiered-support-vs-swarming-part-1/, 2017.

2. Mvungi, M. Knowledge Management Model for Information Technology Support Service / M. Mvungi, I. Jay // Electronic Journal of Knowledge Management.- 2019. - Volume 7, Issue 3. - P.353-366.

3. Kesner, R.M. Developing an Information Technology Support Model for Higher Education / R.M.Kesner // CAUSE/EFFECT. - 1997. - Volume 20, Number 2. - P.24-30.

4. Іванова В.В. Модель організації інформаційного забезпечення економіки, заснованої на знаннях / В. В. Іванова // Економіка і прогнозування. - К.: Інститут економіки та прогнозування НАН України, 2011. - № 3. - С.25-41.

5. Бочкарев, А.М. Модель управления системой информационного обеспечения производственной деятельности предприятия / А.М. Бочкарев // Вестник Удмуртского университета. - Ижевск: УдГУ,2015. - Т.25, Вип.4. - С.35-42.

6. Зубрецька, Н.А. Концептуальна модель системи інформаційного забезпечення якості промислової продукції / Н.А. Зубрецька // Вісник Київського національного університету технологій та дизайну. - К.: КНУТД, 2012. - № 3 (65). - С. 68-74.

7. Овсяннікова Л. Концептуальна модель розвитку системи інформаційного забезпечення медичної науки в Україні / Л. Овсяннікова, Н. Артамонова // Вісник Книжкової палати. - К.: Навчальна книга-Богдан, 2010. - № 6. - С. 24-30.

8. Муляр, І.В. Модель оцінки ймовірнісно-часових характеристик інформаційної взаємодії в мережі інтернет речей / І.В. Муляр, О.В. Сєлюков, В.М. Джулій, Б.М. Кізюн // Збірник наукових праць Військового інституту Київського національного університету імені Тараса Шевченка. - К.: ВІКНУ, 2019. - Вип. № 63. - С.96-107. 
9. Гріненко, О.О. Модель інформаційної взаємодії в екосистемах програмного забезпечення / О.О. Гріненко, С. А. Гріненко // Телекомунікаційні та інформаційні технології. - К.: Державний університет телекомунікацій, 2017. - № 1. - С.104-112.

10. Джулій, В.М. Модель формування цілей інформаційного забезпечення підтримки процесів надання знань / В.М. Джулій, І.В. Гурман, А.А. Маковей, О.В. Мірошніченко // Збірник наукових праць Військового інституту Київського національного університету імені Тараса Шевченка. - К.: ВІКНУ, 2019. - Вип. № 63. - С.85-95

11. Lipka, A. What's Wrong With Today's IT Support Model In Organizations And How Will It Look In The Future? [Electronic resource]. - Mode of access: https://predica.pl/blog/it-support-model-inorganizations/, 2018.

12. Сторчоус М. Д. Загальна концептуальна модель інфомаційно-аналітичної системи забезпечення управління земельними ресурсами населеного пункту / М.Д. Сторчоус // Вісник Черкаського університету. - Черкаси.: Черкаський НУ, 2015. - №38(371). - С.36-43.

13. Павленко Л. А. Концепція інтеграції OLAP і ГІС-технологій в моделях систем підтримки прийняття рішень / Л. А. Павленко // Системи обробки інформації. - 2011. - Вип. 3. - С. 210-213.

14. Алпайдин, Э. Машинное обучение: новый искусственный интеллект / Э. Алпайдин : пер. с англ. - М. : Альпина Паблишер, 2017. - 208 с.

15. Баранчеев, В.П. Управление знаниями в инновационной сфере: учебник / В.П. Баранчеев М.: ООО «Благовест-В», 2007. - 272 с.

16. Лапшин, В.А. Онтологии в компьютерных системах /В.А. Лапшин - М.: Научный мир, 2010. $-222 \mathrm{c}$.

17. Левитин, А. В. Алгоритмы. Введение в разработку и анализ / А. В. Левитин - М. : Вильямс, 2006. $-576 \mathrm{c}$.

18. Олифер, В. Г. Компьютерные сети. Принципы, технологии, протоколы /В. Г. Олифер, Н. А. Олифер - СПб.: Питер, 2017. - 992 с.

19. Советов, Б. Я. Моделирование систем : учебник для бакалавров / Б. Я. Советов, С. А. Яковлев. - 7-е изд. - М. : Издательство Юрайт, 2015. - 343 с.

20. Тархов, Д. А. Нейросетевые модели и алгоритмы : справочник / Д. А. Тархов. - М. : Радиотехника, 2014. - 349 с.

21. Ханссон Д. Х. Гибкая разработка веб-приложений в среде Rails / Д. Х. Ханссон, Д. ТомасСПб.: Питер, 2008. - 720с.

\section{REFERENCES:}

1 Dooley P. (2017), ”Evaluating Technical Support Models: Tiered Support vs. Swarming, Part 1.” [Electronic resource], Mode of access: https://optimalconnections.wordpress.com /2017/08/07/evaluatingtechnical-support-models-tiered-support-vs-swarming-part-1/.

2. Mvungi M. and Jay I. (2019),'Knowledge Management Model for Information Technology Support Service" / M. Mvungi, I. Jay // Electronic Journal of Knowledge Management.-. - Volume 7, Issue 3. pp.353-366.

3. Kesner, R.M. (1997) "Developing an Information Technology Support Model for Higher Education", CAUSE/EFFECT. Volume 20, Number 2, pp.24-30.

4. Ivanova V.V. (2011) "Model' orhanizatsiyi informatsiynoho zabezpechennya ekonomiky, zasnovanoyi na znannyakh" [Model of organization of information support of knowledge based economy], Ekonomika i prohnozuvannya, № 3, pp.25-41.

5. Bochkarev A.M. (2015) "Model' upravleniya sistemoy informatsionnogo obespecheniya proizvodstvennoy deyatel'nosti predpriyatiya" [The management model of the information support system for the production activities of the enterprise], Vestnik Udmurtskogo universiteta, T.25, Vip.4, pp.35-42.

6. Zubrets'ka N.A. (2012) 'Kontseptual'na model' systemy informatsiynoho zabezpechennya yakosti promyslovoyi produktsiyi" [The conceptual model of the system of information quality assurance of industrial production], Visnyk Kyyivs'koho natsional'noho universytetu tekhnolohiy ta dyzaynu, № 3 (65), pp. 68-74.

7. Ovsyannikova L. and Artamonova N. (2010) "Kontseptual'na model' rozvytku systemy informatsiynoho zabezpechennya medychnoyi nauky v Ukrayini" [Conceptual model of development of information support system of medical science in Ukraine], Visnyk Knyzhkovoyi palaty, № 6, pp.24-30.

8. Mulyar I.V., Selyukov O.V., DzhuliyV.M. and Kizyun B.M.(2019) "Model' otsinky ymovirnisnochasovykh kharakterystyk informatsiynoyi vzayemodiyi v merezhi internet rechey" [Model of estimation of probabilistic-temporal characteristics of information interaction in the Internet of things network], Zbirnyk 
naukovyh prac' Vijs'kovogo instytutu Kyi'vs'kogo nacional'nogo universytetu imeni Tarasa Shevchenka, №63, pp.96-107.

9. Grinenko O.O. and Grinenko S.A. (2017) "Model' informatsiynoyi vzayemodiyi v ekosystemakh prohramnoho zabezpechennya" [Model of information interaction in software ecosystems], Telecommunication and information technologies, № 1, pp.104-112.

10. Dzhuliy, V.M., Gurman I.V., Macovey A.A. and Miroshnichenko O.V. (2019) "Model' formuvannya tsiley informatsiynoho zabezpechennya pidtrymky protsesiv nadannya znan"' [A model for the formation of information support goals for knowledge support processes], Zbirnyk naukovyh prac' Vijs'kovogo instytutu Kyi'vs'kogo nacional'nogo universytetu imeni Tarasa Shevchenka, №63, pp. 85-95

11. Lipka A. (2018) "What 's Wrong With Today' s IT Support Model In Organizations And How Will It Look In The Future?", [Electronic resource], Mode of access: https://predica.pl/blog/it-support-model-inorganizations/, 2018.

12. Storchous M.D. (2015) “Zahal'na kontseptual'na model' infomatsiyno-analitychnoyi systemy zabezpechennya upravlinnya zemel'nymy resursamy naselenoho punktu" [The general conceptual model of the information-analytical system of ensuring the management of land resources of the settlement], Visnyk Cherkas'koho universytetu, №38 (371), pp.36-43.

13. Pavlenko L.A. (2011) "KontseptsIya Integratsiyi OLAP I GIS-tehnologiy v modelyah sistem pidtrimki priynyattya rishen" [The concept of integration of OLAP and GIS technologies in models of decision support systems] / LA Pavlenko // Systemy obrobky informatsiyi, Vyp. 3, pp. 210-213.

14. Alpaydin E. (2017),"Mashinnoe obuchenie: novyiy iskusstvennyiy intellekt"'[Machine Learning: New Artificial Intelligence], per. s angl., M. : Alpina Pablisher, 208 p.

15. Barancheev V.P. (2007),"Upravlenie znaniyami v innovatsionnoy sfere: uchebnik.”[Knowledge management in innovation: textbook], M. : OOO «Blagovest-V», 272p.

16. Lapshin V.A. (2010),’Ontologii v kompyuternyih sistemah.'[Ontologies in computer systems], M. : Nauchnyiy mir, 222p.

17. Levitin A.V. (2006),"Algoritmyi. Vvedenie v razrabotku i analiz"[Algorithms. Introduction to the development and analysis], M. : Vilyams, 576p.

18. Olifer V.G. and Olifer, N. A. (2017),"Kompyuternyie seti. Printsipyi, tehnologii, protokolyi " [Computer networks. Principles, technologies, protocols], SPb.: Piter, 992p.

19. Sovetov B.Ya. and Yakovlev S.A. (2015), "Modelirovanie sistem : uchebnik dlya bakalavrov" [System modeling: a textbook for bachelors] , 7-e izd. M. : Izdatelstvo Yurayt, 343p.

20. Tarhov D.A. (2014),'Neyrosetevyie modeli i algoritmyi: spravochnik" [Neural network models and algorithms: a reference book], M. : Radio- tehnika, 349p.

21. Hansson D.X. and Tomas D. (2008),"Gibkaya razrabotka veb-prilozheniy v srede Rails" [Flexible development of web applications in the Rails environment], SPb.: Piter, 720p.

к.т.н., доц. Джулий В.Н., к.т.н., доц. Муляр И.В., д.т.н., с.н.с. Селюков А.В., к.т.н., доц. Чешун В.Н., Коровченко Д.В., Берназ А.А. ИЕРАРХИЧЕСКАЯ СЕТЕВАЯ МОДЕЛЬ ИНФОРМАЦИОННОГО ОБЕСПЕЧЕНИЯ ПРЕДСТАВЛЕНИЯ ПРЕДМЕТНОЙ ОБЛАСТИ

В статье предложен подход к определению иерархической сетевой модели информационного обеспечения представления предметной области. Иерархическая сетевая модель отражает взаимосвязь информационных объектов по уровням подчиненности. Один из ключевых вопросов в разработке информационного обеспечения - выбор модели представления контента таким образом, чтобы обеспечить наиболее эффективную работу с ней как пользователя, так и разработчика. Можно выделить два основных подхода - эмпирический и теоретический. Первый основан на изучении принципов организации человеческой памяти и моделировании механизмов решения задач человеком. Второй подход можно определить, как теоретически обоснованный, что гарантирует правильность решений, а соответствующие ему модели - формальными моделями представления знаний. Последовательность применения материалов включена в состав модели, поскольку эффективность восприятия материала зависит, в том числе, от того, насколько человек «готов" воспринимать предложенную информацию, то есть, имеет достаточно базовых знаний.

В зависимости от вида входных данных предложены возможные способы формирования иерархических сетевых моделей информационного обеспечения. Если входные данные представлены множеством информационных элементов, количество которых сравнительно невелико и приемлемо для применения экспертных методов, предложен алгоритм построения иерархиче- 
ской сетевой двухуровневой модели информационного обеспечения. Если входные данные представлены "Деревом знаний", то есть, иерархической моделью информационного обеспечения, предложсеный алгоритм построения иерархической сетевой модели.

Иерархическая сетевая модель информационного обеспечения, предназначена для управления процессами приобретения и использования знаний, позволяет учитывать полезность информационных элементов и дидактические связи между ними. Предложен способ формирования информационного обеспечения, предназначенный для иерархического сетевого представления предметной области, который позволяет структурировать контент информационносправочных и других систем, отличающихся от известных использованием взаимосвязанных этапов отбора, кластеризации и упорядочения контента

Полученные результаты могут быть использованы для поддержки принятия рещений при приобретении и применении знаний: при разработке программ отдельных курсов повышения квалификации; информационного обеспечения систем электронного обучения; при формировании программ дистанционного образования; при разработке и последующей корректировке учебных планов; формировании учебных, справочных материалов, курсов лекций для отдельных дисциплин.

Ключевые слова: алгоритм, информационный элемент, контент, модель, информационное обеспечение, предметная область, информация.

\section{Ph.D. Dzhulij V.M., Ph.D. Mulyar I.V., prof. Selukov A.V., Ph.D. Cheshun V.M., Korovchenko D.V.,Bernaz A.A. IERARCHIC NETWORK MODEL OF SUBMITTED DOMAIN INFORMATION SUPPLY}

The article proposes an approach to determining the hierarchical network model of information provision representation of the submitted domain. The hierarchical network model represents the interconnection of information objects by subordination levels.

One of the key issues in the development of information provision is the choice of the content delivery model in such a way as to ensure the most effective work with it as a user and developer. There are two main approaches - empirical and theoretical. The first is based on the study of the organization principles of human memory and the simulation of solving human problems mechanisms. The second approach can be defined as theoretically substantiated, which guarantees the correctness of the solutions, and the corresponding models - formal models of presentation of knowledge. The sequence of application of materials is included in the model, since the effectiveness of the perception of the material depends, among other things, on how much the person is "ready" to perceive the proposed information, that is, has a rather basic knowledge.

Depending on the type of input data, possible ways of forming hierarchical network models of information support are proposed. If the input data is represented by a plurality of information elements, the number of which is relatively small and possible for the application of expert methods, the algorithm for constructing a hierarchical network two-level model of information provision is proposed. If the input data is represented by the "Tree of Knowledge", that is, the hierarchical model of information support, the algorithm for constructing a hierarchical network model is proposed.

The hierarchical network model of information support, designed to manage the processes of acquisition and use of knowledge, which allows you to take into account the usefulness of information elements and didactic connections between them. The method of information support formation is proposed for the hierarchical network representation of the subject area, which allows to structure the information content and reference and other systems, which differ from the known of selection interrelated stages, clustering and content streamlining.

The obtained results can be used to support decision-making in the acquisition and application of knowledge: in developing programs of individual advanced training courses; informational support of electronic learning systems; when forming distant education programs; in the development and subsequent adjustment of curricula; the formation of educational, reference materials, lecture courses for individual disciplines.

Keywords: algorithm, information element, content, model, information provision, subject area, information. 